\title{
Catalytic Light Alkanes Conversion through Anaerobic Ammodehydrogenation
}

Genwei Chen, ${ }^{1 \ddagger}$ Tingyu Liang, ${ }^{1 \ddagger}$ Pilsun Yoo, ${ }^{2 \ddagger}$ Siavash Fadaeerayeni, ${ }^{1 \ddagger}$ Erik Sarnello, ${ }^{3}$ Tao Li, ${ }^{3,4}$

1. Dave C. Swalm School of Chemical Engineering, Mississippi State University, Starkville, MS 39762, United States

2. School of Materials Engineering, Purdue University, West Lafayette, IN 47906, USA

3. Department of Chemistry and Biochemistry, Northern Illinois University, DeKalb, Illinois 60115, United States

4. X-ray Science Division, Argonne National Laboratory, Lemont, Illinois 60439, United States 


\section{Experimentals}

Catalyst preparation: The $\mathrm{Rh}, \mathrm{Ru}$, and Pd modified HZSM-5 catalysts were prepared through the same impregnation procedures described for the Pt/HZSM-5 catalyst. Rhodium(III) chloride (Millipore Sigma), Ruthenium(III) chloride (Millipore Sigma), and Palladium(II) acetate (Millipore Sigma) were used as the precursor. The SAR of the zeolite is 15, and the nominal metalbased loading is $0.5 \mathrm{wt} \%$. The non-noble metal, Ga, Zn, Re, Ni, and Co modified HZSM-5 $(S A R=15)$ catalysts were also prepared through impregnation. Gallium(III) nitrate hydrate (Millipore Sigma, 98+), zinc nitrate hexahydrate (Millipore Sigma, 98\%), ammonium perrhenate (Chemsavers Inc), nickel(II) nitrate hexahydrate (Millipore Sigma, 98.5\%), and cobalt(II) nitrate hexahydrate (Millipore Sigma, 98\%) were used as the precursors of the metal species. The nominal metal-based loading is 2 wt\%. Other non-noble metals, Sn, Cu, Fe, Mn, Ce, Zr, Ti, In, and Mo modified HZSM-5 catalysts were also prepared and tested for ethane ADeH. However, preliminary studies show negligible activity or totally inactive. Additionally, the Pt modified other zeolites are also active in the ADeH. However, preliminary catalytic tests found that catalyst with the ZSM-5 as the support was more active than the other zeolites (Beta, Mordenite, and Ferrierite).

$\mathrm{C}_{2} \mathrm{H}_{6} / \mathbf{D}_{2}$ exchange: The $\mathrm{C}_{2} \mathrm{H}_{6} / \mathrm{D}_{2}$ exchange was performed in the same reactor system for the transient kinetic exterments. Typically, $0.1 \mathrm{~g}$ of the catalyst was activated in $\mathrm{Ar}(30 \mathrm{ml} / \mathrm{min})$ at $650^{\circ} \mathrm{C}$ (ramp $10^{\circ} \mathrm{C} / \mathrm{min}$ ) for $30 \mathrm{~min}$. The temperature of the reactor then decreased to $300^{\circ} \mathrm{C}$ for $\mathrm{C}_{2} \mathrm{H}_{6} / \mathrm{D}_{2}$ exchange under both steady-state and the isotopic transient. Before each experiment, the

20 bypass feed spectra, as well as the inert Ar signal, were recorded for mass spectrometer calibration and used as a reference for activity calculation. The isotopic exchange was initiated by switching the influent gas from $30 \mathrm{ml} / \mathrm{min}$ Ar to $20 \mathrm{ml} / \mathrm{min}_{2} \mathrm{H}_{6}+10 \mathrm{ml} / \mathrm{min}_{2}$ under atmospheric pressure at a gas hourly space velocity (GHSV) of $12000 \mathrm{~h}^{-1}$. After the isotopic exchange reaches the steadystate, the reactor influent was switched from $20 \mathrm{ml} / \mathrm{min} \mathrm{C}_{2} \mathrm{H}_{6}+10 \mathrm{ml} / \mathrm{min}_{2}$ to $20 \mathrm{ml} / \mathrm{min}_{2} \mathrm{H}_{6}$ $+10 \mathrm{ml} / \mathrm{min} \mathrm{H}_{2}$. In order to investigate the influence of $\mathrm{NH}_{3}$ on the $\mathrm{C}-\mathrm{H}$ bond activation, the $\mathrm{C}_{2} \mathrm{H}_{6} / \mathrm{D}_{2}$ exchange was performed on both clean catalyst surface and $\mathrm{NH}_{3}$ chemisorbed catalyst. $\mathrm{NH}_{3}$ pre-adsorption before the $\mathrm{C}_{2} \mathrm{H}_{6} / \mathrm{D}_{2}$ exchange was realized through flowing pure $\mathrm{NH}_{3}$ (20 $\mathrm{ml} / \mathrm{min}$ ) at $300^{\circ} \mathrm{C}$ for $20 \mathrm{~min}$ followed by flushing with Ar for $30 \mathrm{~min}$. The reactor effluent was measured by the same online Agilent 5973 mass spectrometer. 
Reactions with pulse feed inject: Direct reaction of ethylamine with $\mathrm{NH}_{3}$ under $\mathrm{ADeH}$ identical conditions were performed through pulse injection. The ethylamine ( $2 \mu \mathrm{L}$ liquid) was injected into the reactor through a syringe and was carried to the surface of the catalyst through $50 \% \mathrm{NH}_{3}$ flow (40 $\mathrm{ml} / \mathrm{min})$.

Quantification with mass spectrometer: In order to make quantitative analysis by the Mass Spectrometer, various mass to charge ratio, such as $\mathrm{m} / \mathrm{z}=16, \mathrm{~m} / \mathrm{z}=17, \mathrm{~m} / \mathrm{z}=26, \mathrm{~m} / \mathrm{z}=27, \mathrm{~m} / \mathrm{z}=30$, $\mathrm{m} / \mathrm{z}=40, \mathrm{~m} / \mathrm{z}=41, \mathrm{~m} / \mathrm{z}=78, \mathrm{~m} / \mathrm{z}=92$ and $\mathrm{m} / \mathrm{z}=106$, were monitored simultaneously. The intensity of the $\mathrm{m} / \mathrm{z}$ signal $\left(\mathrm{I}_{\mathrm{m} / \mathrm{z}}\right)$ then converted to the intensity of each molecule ( $\mathrm{I}_{\text {molecule}}$ ) based on the quantitative calibration. Apparently, $\mathrm{I}_{\text {Ammonia }}=\mathrm{I}_{17}, \mathrm{I}_{\text {Ethane }}=\mathrm{I}_{30}, \mathrm{I}_{\mathrm{Ar}}=\mathrm{I}_{40}, \mathrm{I}_{\text {Acetonitrile }}=\mathrm{I}_{41}, \mathrm{I}_{\text {Benzene }}=\mathrm{I}_{78}$, $\mathrm{I}_{\text {Toluene }}=\mathrm{I}_{92}$, and $\mathrm{I}_{\mathrm{xylene}}=\mathrm{I}_{106}$. The quantification of $\mathrm{I}_{\text {Methane, }} \mathrm{I}_{\mathrm{Ethylene}}$, and $\mathrm{I}_{\mathrm{HCN}}$ was different because they have overlapped $\mathrm{m} / \mathrm{z}$ signal to ammonia and ethane, respectively. The IMethane was calculated by excluding the contribution of $\mathrm{NH}_{3}$ to the signal of $\mathrm{m} / \mathrm{z}=16$. The $\mathrm{I}_{\text {Ethylene }}$ and $\mathrm{I}_{\mathrm{HCN}}$ were deconvoluted from ethane through matrix method. ${ }^{1}$ The obtained intensity of each molecule was converted to partial pressure based on the external calibration, which finally calculated to each molecules' mole flowrate (mol/s) based on the ideal gas equation $\left(P_{i} v_{t o t}=F_{i} R T\right)$, where $P_{i}$ is the partial pressure of selected molecules $(\mathrm{Pa}), \mathrm{V}_{\text {tot }}$ is the total volumetric flow rate $(\mathrm{ml} / \mathrm{min}), \mathrm{F}_{\mathrm{i}}$ is the mole flow rate $(\mathrm{mol} / \mathrm{min}), \mathrm{R}$ is the ideal gas constant $(\mathrm{J} / \mathrm{mol} / \mathrm{K})$, and $\mathrm{T}$ is the temperature $(\mathrm{K})$.

The rate of different products was calculated based

$$
r_{i}=\frac{F_{i}}{m_{\text {Cat }}} \text { or }=\frac{F_{i}}{m_{P t}}
$$

where $m_{C a t}$ is the mass of catalyst used for the reaction, and $m_{P t}$ is the mass of Pt in the catalyst used for the reaction.

The conversion of ethane was calculated based on:

$$
\mathrm{x}=\frac{\mathrm{F}_{\mathrm{i}, \text { out }} \times n}{2 \times \mathrm{F}_{\text {ethane, in }}} \times 100 \%
$$

The carbon-based selectivity of each product was calculated based on:

$$
\mathrm{S}_{\mathrm{i}}=\frac{\mathrm{F}_{\mathrm{i}, \text { out }} \times n}{\left(\mathrm{~F}_{\text {ethane, in }}-\mathrm{F}_{\text {ethane, out }}\right) \times 2} \times 100 \%
$$

where " $n$ " represents the carbon number in the molecular of product $i$. 
The deviation of the total carbon balance at $500^{\circ} \mathrm{C}$ :

$$
\Delta \mathrm{C}=\left|\frac{\sum C_{\text {in }}-\sum C_{\text {out }}}{\sum C_{\text {in }}}\right| \leq 7 \%
$$

Computational Details: We conducted the following process to build the $\mathrm{Pt}_{20} / \mathrm{HZSM}-5$ geometry for further reaction study. From different sizes of Pt clusters (6 atoms $\sim 50$ atoms), we selected a $\mathrm{Pt}_{20}$ cluster because it was comparable in size to fit in a single channel of HZSM-5, and has more than $3 \mathrm{Pt}$ atoms exposed as possible reaction sites. As the first step, the genetic algorithm proposed by Vilhelmsen and Hammer ${ }^{2}$ along with the effective medium theory (EMT) potential ${ }^{3}$ was used to generate initial structures of the $\mathrm{Pt}_{20}$ clusters. A hundred structures from this geometry search were assigned for DFT calculations to get single point energies without geometry optimization. The lowest energy structures were then selected and fully optimized in a $25 \AA$ cubic box with DFT. The zeolite framework with the Bronsted acid site (HZSM-5) was optimized for the cell parameters and ionic positions. We then plugged the optimized $\mathrm{Pt}_{20}$ cluster into a zigzag pore with $~ 5.4 \AA$ diameter near the T12 (tetrahedral 12) Brønsted acid site of HZSM-5, to investigate the effects of both Brønsted acid site of HZSM-5 and Pt 20 for the catalytic reactions. Finally, the geometry of $\mathrm{Pt}_{20} / \mathrm{HZSM}-5$ was optimized for ionic positions with fixed lattice parameters of HZSM-5, to model the high dispersion and low density of Pt clusters in the experiments. The Gibbs free energy changes of the reactions were calculated using the following equation: $\Delta G=\Delta H_{f}-T \Delta S=$ $\Delta E_{D F T}+\Delta E_{Z P E}-T \Delta S_{g a s}$. The enthalpy term was calculated using DFT with the energy difference $\left(\Delta E_{D F T}\right)$ and the zero-point energy $\left(\Delta E_{Z P E}\right)$ contributions. Assuming the entropy of surface adsorbed intermediates was small, we only include the entropy change from the gas phase entropy $\left(\Delta S_{\text {gas }}\right)$. The entropy values of gas phase were collected from the NIST Chemistry WebBook ${ }^{4}$ and the CRC handbook of chemistry and physics. ${ }^{5}$

Supplementary DFT Discussion: The ethane dehydrogenation on $\mathrm{Pt}_{20}$ cluster was driven by the favorable enthalpy of adsorption for ethane by $-92 \mathrm{~kJ} / \mathrm{mol}$ at $\mathrm{Pt}_{20}$ cluster and no adsorption of $\mathrm{C}_{2} \mathrm{H}_{6}$ at the Bronsted acid site (likely due to fully saturated covalent bonding of C). The reaction was initiated by activating one of the $\mathrm{C}-\mathrm{H}$ bonds to form $\mathrm{CH}_{2} \mathrm{CH}_{3}$ and $\mathrm{H}$ over $\mathrm{Pt}_{20}$ cluster with $\Delta G^{\ddagger}=$ $77 \mathrm{~kJ} / \mathrm{mol}$. The subsequent C-H bond scission (TS2) for the $\mathrm{CH}_{3}$ of $\mathrm{CH}_{2} \mathrm{CH}_{3}$ was a more favorable process with $\Delta G^{\ddagger}=60 \mathrm{~kJ} / \mathrm{mol}$ in Figure S10 b. 
The Brønsted acid site of HZSM-5 zeolite framework was considered as the main reaction site to form ethylamine formation (C-N linkage). The adsorption of $\mathrm{C}_{2} \mathrm{H}_{4}$ on Brønsted acid site was initiated by transferring the hydrogen of Brønsted acid site to one of the carbon atoms of $\mathrm{C}_{2} \mathrm{H}_{4}$ with $\Delta G^{\ddagger}=97 \mathrm{~kJ} / \mathrm{mol}$. Meanwhile, the other carbon atom became directly bonded to $\mathrm{Al}$ site with a free energy change of $-30 \mathrm{~kJ} / \mathrm{mol}$. After anchoring the ethylene at Brønsted acid site, the N-C bond formation can be established by a reaction between the $-\mathrm{CH}_{2}$ of $\mathrm{CH}_{2} \mathrm{CH}_{3}$ and nearby $\mathrm{N}$ of $\mathrm{NH}_{3}$ molecule with $\Delta G^{\ddagger}=36 \mathrm{~kJ} / \mathrm{mol}$, with very favorable free energy change by $-97 \mathrm{~kJ} / \mathrm{mol}$. Further rotation of $\mathrm{H}_{3} \mathrm{NCH}_{2} \mathrm{CH}_{3}$ (ethylamine $+\mathrm{H}$ ) was studied with stronger interaction predicted between $-\mathrm{NH}_{3}$ of $\mathrm{H}_{3} \mathrm{NCH}_{2} \mathrm{CH}_{3}$ and $\mathrm{Al}$ site for Brønsted acid site, lowering the free energy by -57

$10 \mathrm{~kJ} / \mathrm{mol}$. The final step was regenerating the Bronsted acid site by $\mathrm{N}-\mathrm{H}$ bond dissociation and desorption of the $\mathrm{H}_{2} \mathrm{NCH}_{2} \mathrm{CH}_{3}$ molecule.

Finally, consecutive N-H/C-H bond scissions from $\mathrm{H}_{2} \mathrm{NCH}_{2} \mathrm{CH}_{3}$ on $\mathrm{Pt}_{20}$ cluster were necessary for $\mathrm{CH}_{3} \mathrm{CN}$ formation. Testing different sequences of the $\mathrm{N}-\mathrm{H} / \mathrm{C}-\mathrm{H}$ bond scissions, we found that two alternative $\mathrm{N}-\mathrm{H}$ and $\mathrm{C}-\mathrm{H}$ bond scission process over $\mathrm{Pt}_{20}$ cluster was the most energetically 15 favorable to form $\mathrm{CH}_{3} \mathrm{CN}$ product. In detail, the first $\mathrm{N}-\mathrm{H}$ bond scission occurred after the adsorption of $\mathrm{N}$ of ethylamine by the single atom of $\mathrm{Pt}_{20}$ cluster. The dehydrogenation of $-\mathrm{NH}_{2}$ of ethylamine took place by the bridge site of $\mathrm{Pt}_{20}$ with $\Delta G^{\ddagger}=121 \mathrm{~kJ} / \mathrm{mol}$ as the largest kinetic barrier of the process. The first $\mathrm{C}-\mathrm{H}$ scission process was transferring $\mathrm{H}$ from $-\mathrm{CH}_{2}$ - with appropriate rotation and bending of adsorbed molecule. The kinetic barrier of this step was $\Delta G^{\ddagger}=18 \mathrm{~kJ} / \mathrm{mol}$.

20 The last two steps have a similar tendency to the first two step with dehydrogenation from $\mathrm{N}$ and C with $\Delta G^{\ddagger}=77 \mathrm{~kJ} / \mathrm{mol}$ (TS3) and $\Delta G^{\ddagger}=48 \mathrm{~kJ} / \mathrm{mol}$ (TS4). Here, the rate limiting-step of the entire process of $\mathrm{CH}_{3} \mathrm{CN}$ formation is $\mathrm{N}-\mathrm{H}$ bond scission of TS1 $\left(\Delta G^{\ddagger}=121 \mathrm{~kJ} / \mathrm{mol}\right)$.

A unique aspect of $\mathrm{Pt}_{20}$ cluster was observed in the study of the reaction mechanisms. First, compared to Pt surfaces from bulk or large nanoparticles, the Pt clusters are fluxional, with their geometry optimized and adjusted for various reactants, intermediates and products adsorption. Overall, the DFT calculations support that $\mathrm{Pt}_{20}$ cluster is a good catalyst to form $\mathrm{CH}_{3} \mathrm{CN}, \mathrm{C}_{2} \mathrm{H}_{4}$ and $\mathrm{H}_{2}$ in conjunction with $\mathrm{H}_{2} \mathrm{NCH}_{2} \mathrm{CH}_{3}$ formation at Brønsted acid site. 

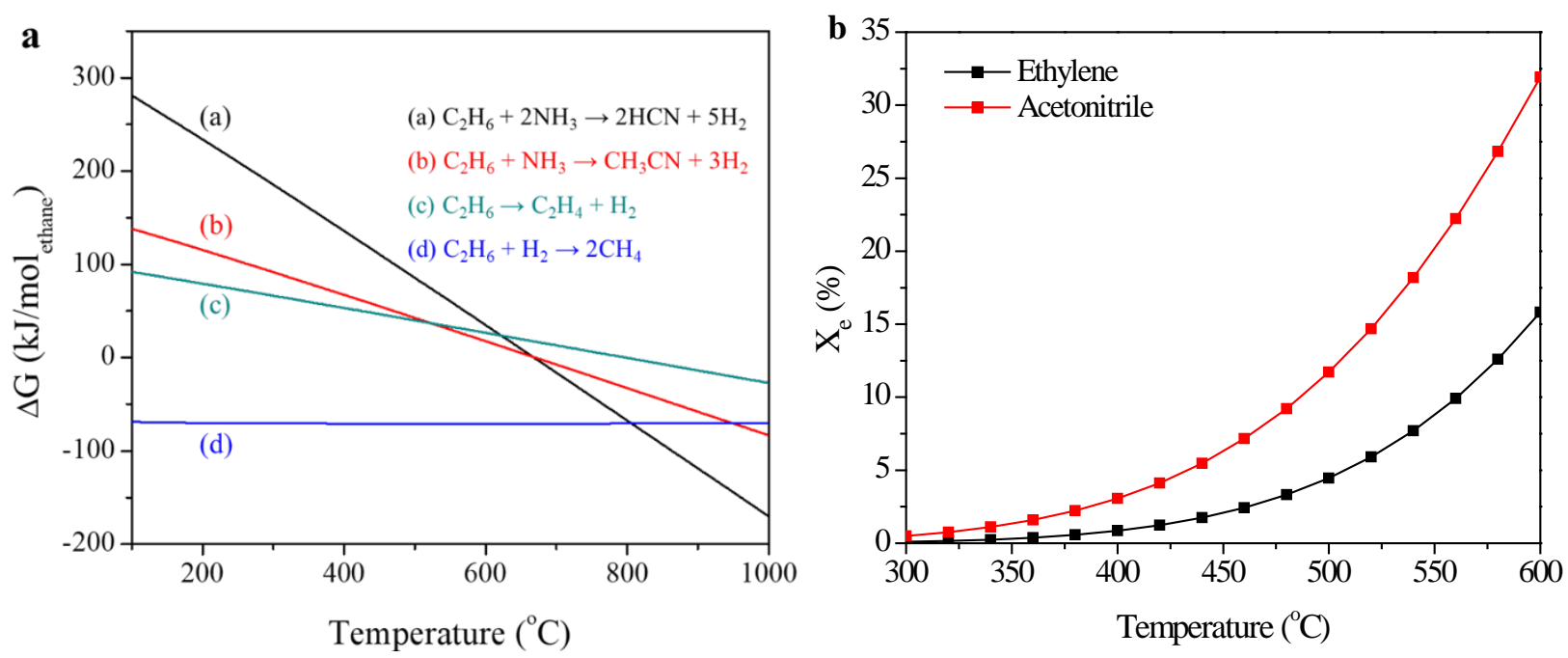

Figure S1. Thermodynamic analysis of ethane ADeH (calculated with HSC Chemistry 6.0). (a) $\Delta \mathrm{G}$ of the involved reactions for different products; (b) influence of temperature on the equilibrium conversion of ethane $\mathrm{ADeH}\left(\mathrm{C}_{2} \mathrm{H}_{6}+\mathrm{NH}_{3} \rightarrow \mathrm{CH}_{3} \mathrm{CN}+3 \mathrm{H}_{2}\right)$ and dehydrogenation $\left(\mathrm{C}_{2} \mathrm{H}_{6} \rightarrow \mathrm{C}_{2} \mathrm{H}_{4}\right.$

$+\mathrm{H}_{2}$ ). The equilibrium conversion of ADeH was calculated based on the initial ethane and $\mathrm{NH}_{3}$ compositions both at $50 \mathrm{~mol} \%$ under atmospheric pressure. The calculation of dehydrogenation was based on $100 \mathrm{~mol} \%$ of ethane under atmospheric pressure. 


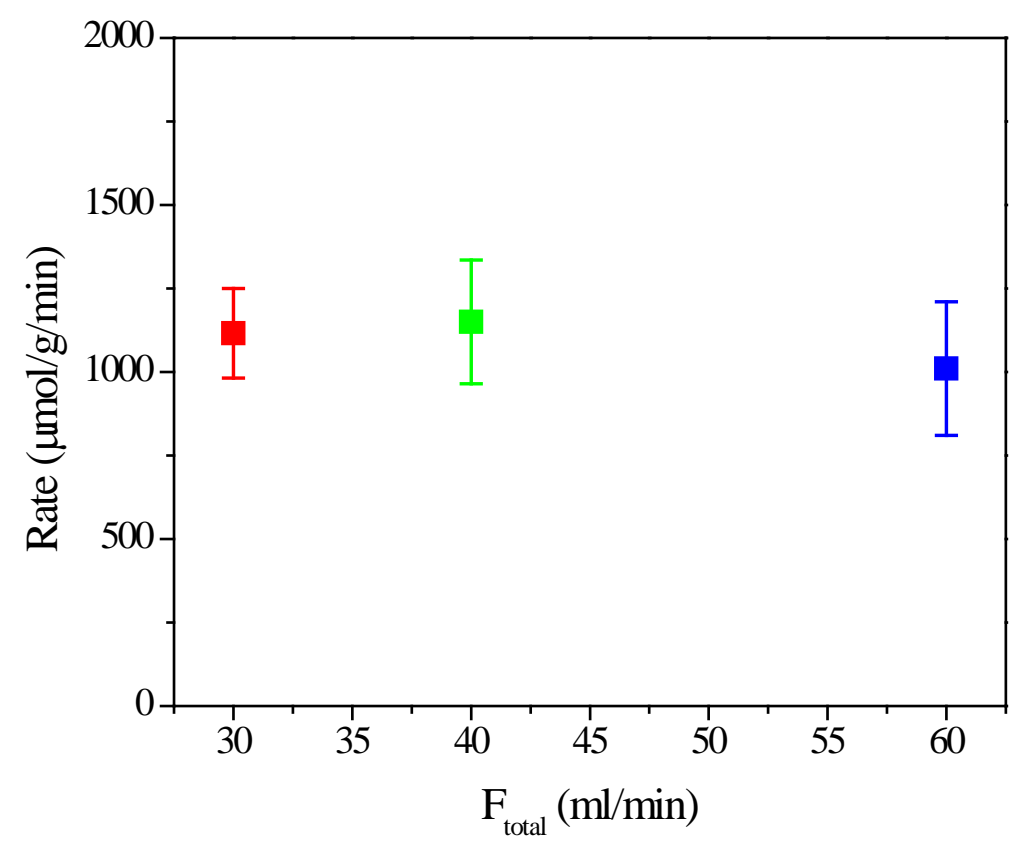

Figure S2. Influence of reactant total flow (external diffusion) on the activity. The reactions were performed at $500^{\circ} \mathrm{C}$ under a GHSV) of $16000 \mathrm{~h}^{-1}$ over the $0.5 \mathrm{wt} \% \mathrm{Pt} / \mathrm{HZSM}-5$ catalyst. The rate remains largely the same with changing total flowrate from 30-60 ml/min under the same GHSV, indicating the reaction was run under kinetic control (absence of external diffusion). Error bar shown in panel (a) was obtained from the catalyst deactivation within TOS of 1 hour. 
ADeH
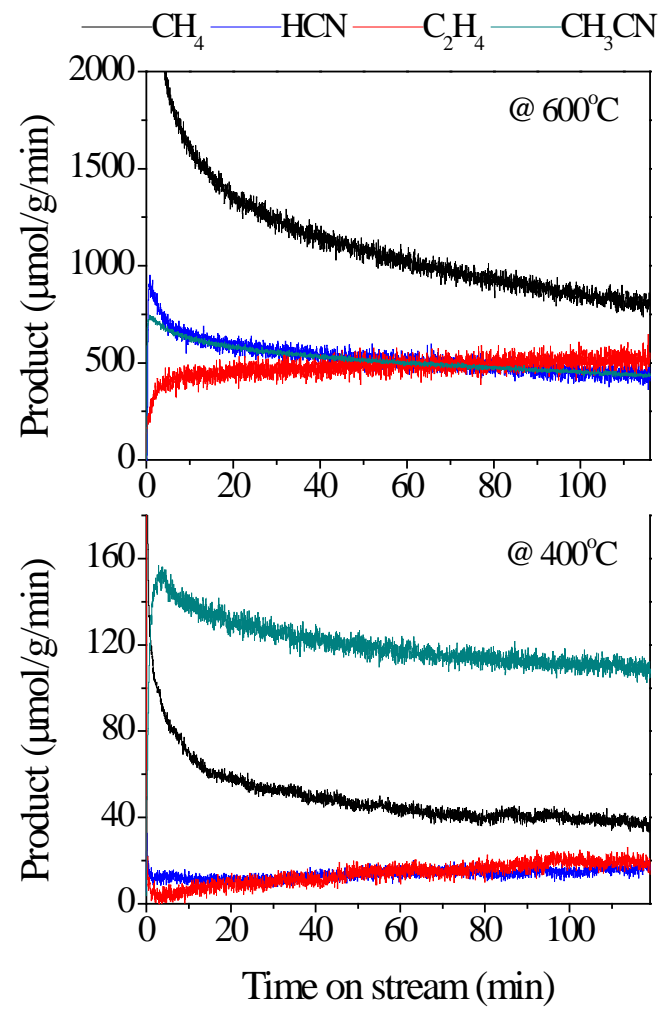

Dehydroaromatization
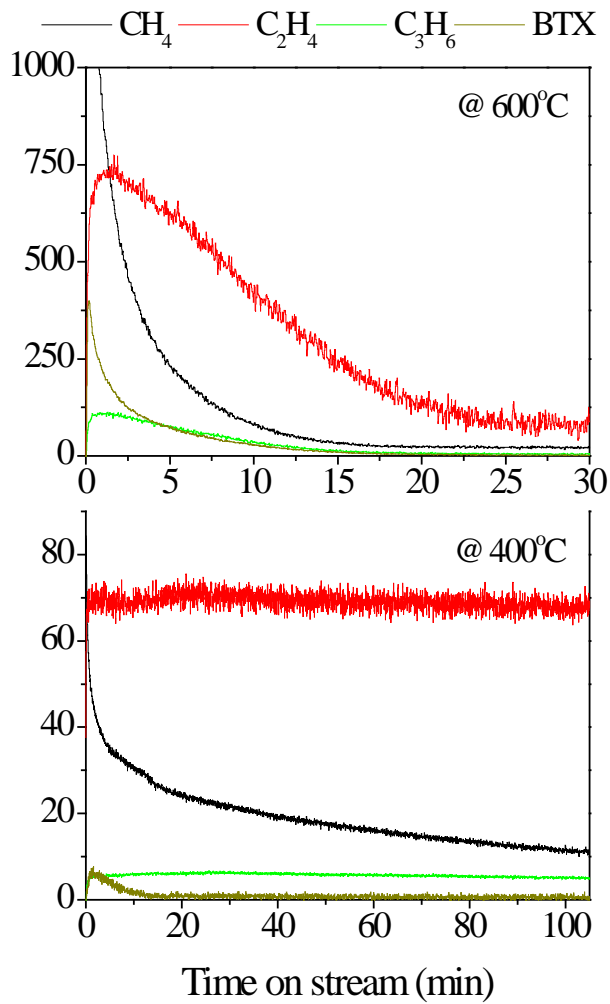

Figure S3. Catalytic results of ethane $\mathrm{ADeH}$ and dehydrogenation or aromatization. Reaction conditions: 0.1 g catalyst (0.5 wt $\%$ Pt/HZSM-5), $\mathrm{P}_{\mathrm{C} 2 \mathrm{H} 6} / \mathrm{P}_{\mathrm{NH} 3}=0.5 / 0.5$ atm for $\mathrm{ADeH}$ and $\mathrm{P}_{\mathrm{C} 2 \mathrm{H} 6} / \mathrm{P}_{\mathrm{Ar}}$ $=0.5 / 0.5$ for dehydrogenation or aromatization, GHSV $=16,000 \mathrm{~h}^{-1}$.

The catalytic data at $600^{\circ} \mathrm{C}$ demonstrated that $\mathrm{ADeH}$ is significantly more stable than aromatization under the same conditions. While all of the products were almost absent after only $30 \mathrm{~min}$ for the aromatization, the rates for $\mathrm{C}_{2} \mathrm{H}_{4}, \mathrm{CH}_{3} \mathrm{CN}$, and $\mathrm{HCN}$ remain stable after nearly 120 min. The catalytic data at $400^{\circ} \mathrm{C}$ demonstrated that the $\mathrm{ADeH}$ shows higher low-temperature reactivity than the dehydrogenation. The total reaction rate of the desired products for the $\mathrm{ADeH}$ is about twice that for the dehydrogenation. 
Table S1. Compilation of catalytic performance data for various catalytic systems for ethane and propane conversion.

\begin{tabular}{|c|c|c|c|c|c|c|c|c|}
\hline \multirow[t]{2}{*}{ Reaction } & \multirow[t]{2}{*}{ Catalyst } & \multirow[t]{2}{*}{$\mathrm{T}\left({ }^{\circ} \mathrm{C}\right)$} & \multicolumn{4}{|c|}{$\mathrm{STY}^{\mathrm{a}}\left(\mu \mathrm{mol} / \mathrm{g}_{\mathrm{cat}} / \mathrm{min}\right)$} & \multirow{2}{*}{$\begin{array}{l}\text { Sel. }^{\mathrm{b}} \\
(\%)\end{array}$} & \multirow[t]{2}{*}{ Ref. } \\
\hline & & & $\mathrm{ACN}$ & $\mathrm{C}_{2} \mathrm{H}_{4}$ & $\mathrm{C}_{3} \mathrm{H}_{6}$ & BTX & & \\
\hline $\mathrm{ADeH}$ & Pt/HZSM-5 & 400 & 130 & 10 & I & / & $>93$ & This work \\
\hline $\mathrm{ADeH}$ & Pt/HZSM-5 & 500 & 484 & 92.7 & I & I & 83 & This work \\
\hline $\mathrm{ADeH}$ & Pt/HZSM-5 & 600 & 1250 & 800 & I & I & 80 & This work \\
\hline $\mathrm{ADeH}^{\mathrm{c}}$ & Pt/HZSM-5 & 400 & / & I & 160 & / & 98 & This work \\
\hline $\mathrm{ADeH}^{\mathrm{c}}$ & Pt/HZSM-5 & 450 & I & I & 375 & l & 85 & This work \\
\hline Ammoxidation & $\mathrm{Co} / \beta$ & 475 & 267 & 85.7 & l & / & 74 & 6 \\
\hline Dehydrogenation & $\mathrm{Pt} / \mathrm{Mg}(\mathrm{Al}) \mathrm{O}$ & 600 & I & 1320 & l & / & 62 & $7-9$ \\
\hline Dehydrogenation & $\mathrm{Pt} / \mathrm{Mg}(\mathrm{In}) \mathrm{O}$ & 600 & / & 1740 & / & / & 98 & $7-9$ \\
\hline Dehydrogenation & $\mathrm{Pt} / \mathrm{Mg}(\mathrm{Ga}) \mathrm{O}$ & 600 & / & 1680 & / & / & 100 & $7-9$ \\
\hline Dehydrogenation & $\mathrm{PtSn} / \mathrm{Mg}(\mathrm{Al}) \mathrm{O}$ & 600 & / & 1620 & l & / & 98 & $7-9$ \\
\hline $\mathrm{CO}_{2}$ dehydrogenation & $\mathrm{Ni}_{1} \mathrm{Fe}_{3} / \mathrm{CeO}_{2}$ & 600 & / & 357 & l & l & 80 & 10 \\
\hline Dehydrogenation ${ }^{\mathrm{c}}$ & $\mathrm{Ni}_{3} \mathrm{Ga} / \mathrm{Al}_{2} \mathrm{O}_{3}$ & 600 & I & l & 80 & I & 95 & 11 \\
\hline $\begin{array}{l}\text { Oxidative } \\
\text { dehydrogenation }{ }^{\mathrm{c}}\end{array}$ & Boron nitride & 490 & I & / & 1587 & / & 80 & 12 \\
\hline Aromatization & Pt/HZSM-5 & 630 & / & / & I & 273 & 60 & 13 \\
\hline
\end{tabular}

a: Recalculated from literature.

b: Total selectivity to useful products.

c: Propane was used as the reactant. 

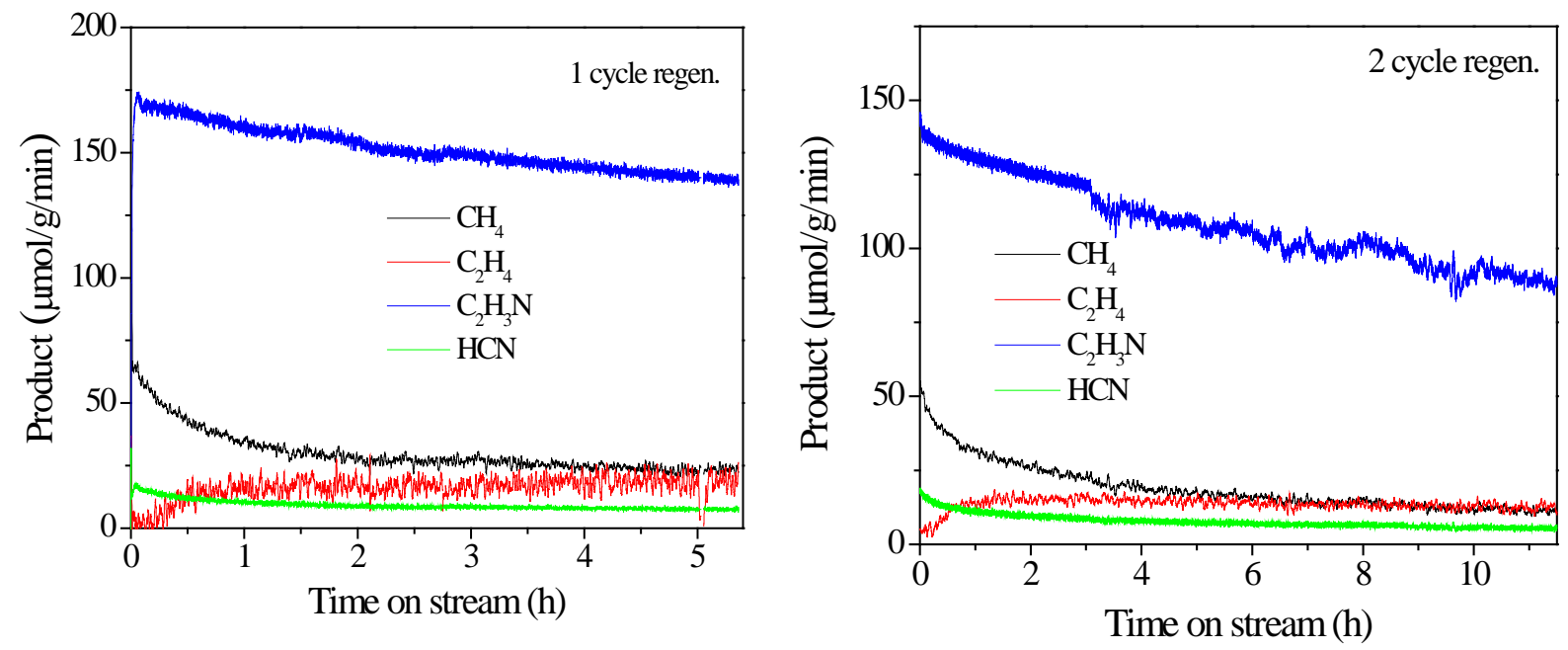

Figure S4. Catalytic performance of ethane $\mathrm{ADeH}$ over the regenerated catalyst. detailed reaction conditions are the same as that shown in Fig. 2.

Regeneration of the deactivated catalysts was realized through coke burn-off in $10 \% \mathrm{O}_{2} / \mathrm{He}$. The used catalyst was first cooled to $100^{\circ} \mathrm{C}$ under Ar flow. Then the same was heated to $650^{\circ} \mathrm{C}$ at $10^{\circ} \mathrm{C} / \mathrm{min}$ and kept at that temperature for $30 \mathrm{~min}$. The catalysts after de-coking were used directly for the next cycle reaction without further activation. 


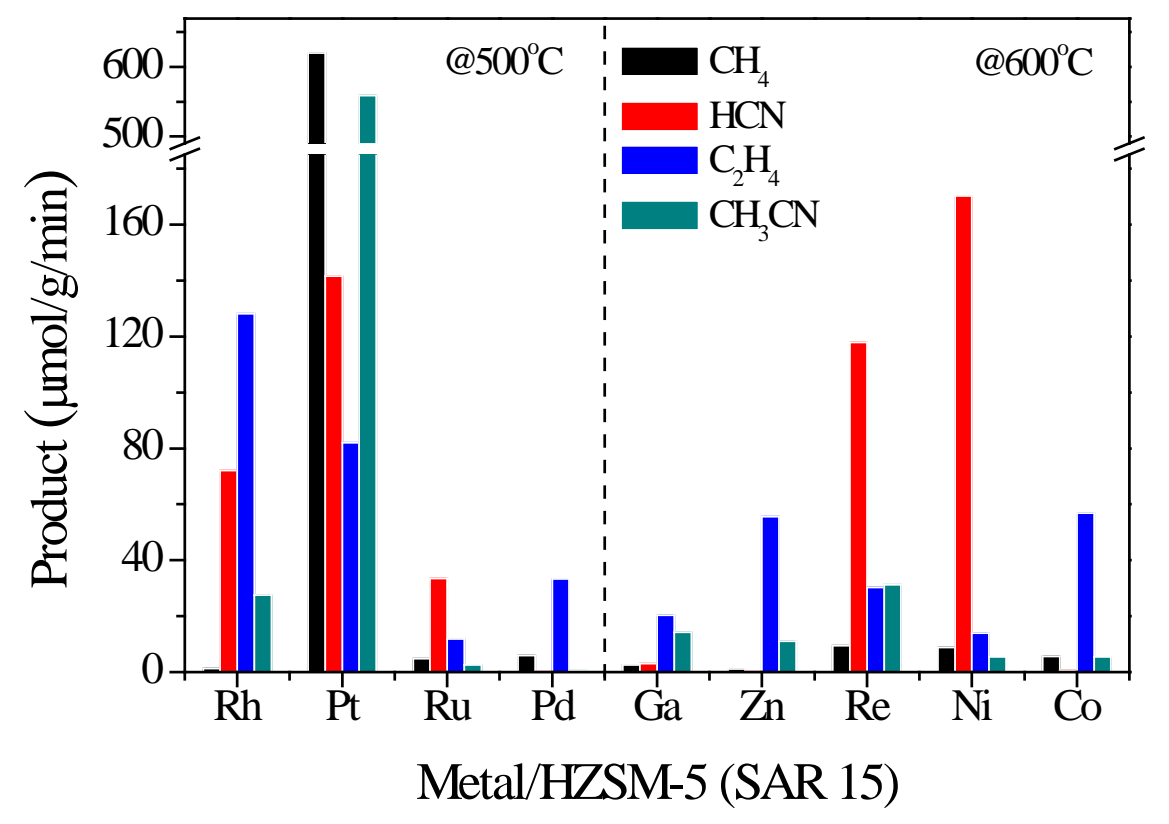

Figure S5. Activities of ethane ADeH over the different metal modified HZSM-5 catalyst. The results demonstrated that the activities of ethane ADeH dependent highly upon the metal function. The platinum group metals modified HZSM-5 catalysts show significant ethane conversion at $500^{\circ} \mathrm{C}$, but all of the non-noble metal catalysts require a higher reaction temperature $\left(\geq 600^{\circ} \mathrm{C}\right)$. 


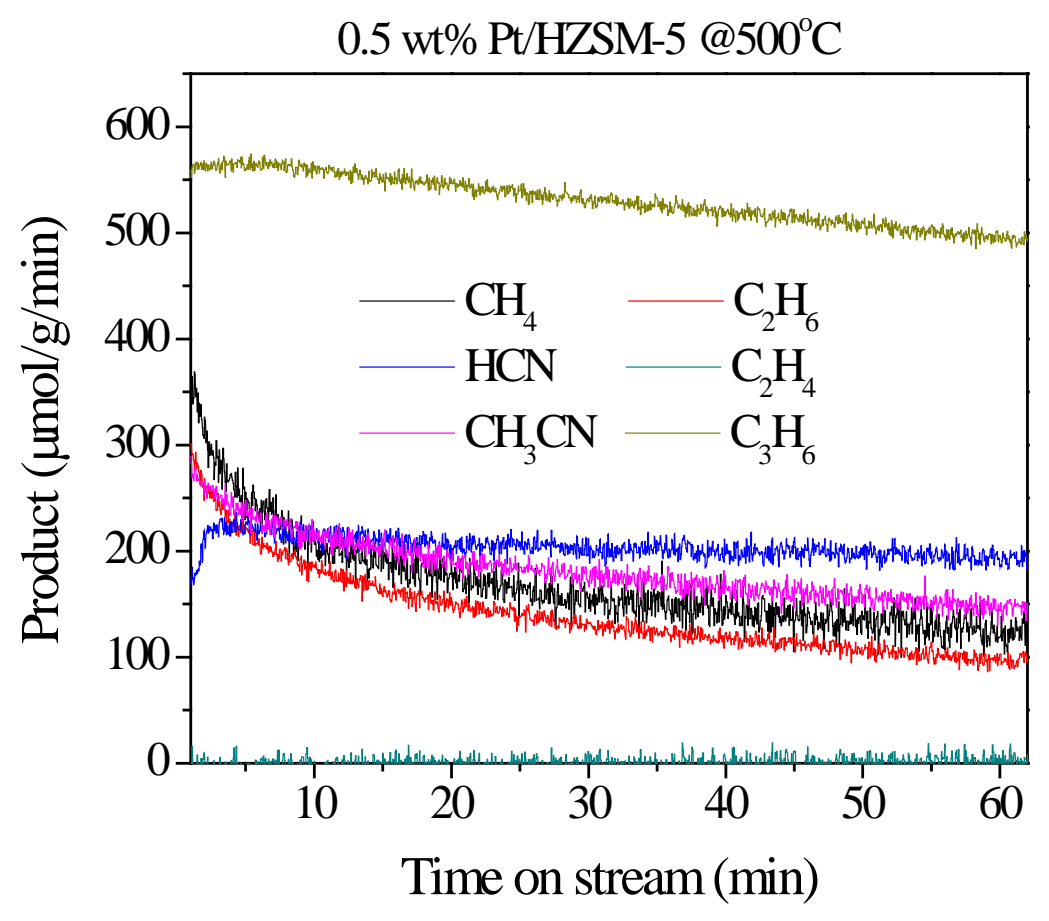

Figure S6. Catalytic results of propane ADeH over the $0.5 \mathrm{wt} \% \mathrm{Pt} / \mathrm{HZSM}-5$ catalyst at $500^{\circ} \mathrm{C}$. Reaction conditions: 0.1 g catalyst, $\mathrm{P}_{\mathrm{C} 2 \mathrm{H} 6} / \mathrm{P}_{\mathrm{NH} 3}$ or $\mathrm{P}_{\mathrm{C} 3 \mathrm{H} 8} / \mathrm{P}_{\mathrm{NH} 3}=0.5 / 0.5 \mathrm{~atm}, \mathrm{GHSV}=16,000 \mathrm{~h}^{-1}$. Over the Pt/HZSM-5 catalyst at $500^{\circ} \mathrm{C}$, propane $\mathrm{ADeH}$ produces mainly propylene at a rate of above $500 \mu \mathrm{mol} / \mathrm{g} / \mathrm{min}$. Additionally, the rates of $\mathrm{CH}_{3} \mathrm{CN}, \mathrm{HCN}, \mathrm{C}_{2} \mathrm{H}_{6}$, and $\mathrm{CH}_{4}$ are range from 100 to $250 \mu \mathrm{mol} / \mathrm{g} / \mathrm{min}$, indicating quite higher activity of C-C bond scission. 

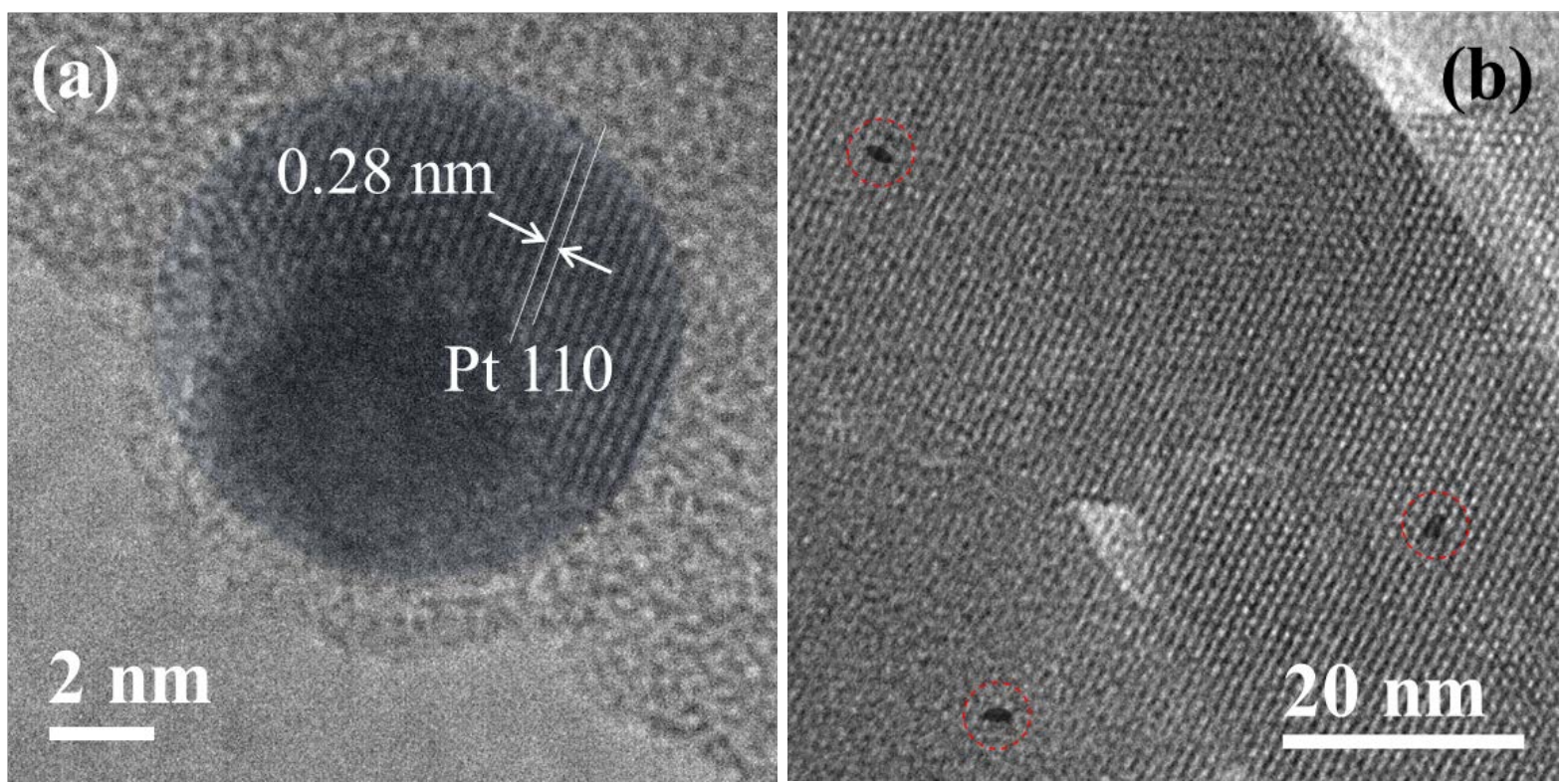

Figure S7. TEM images of $0.5 \mathrm{wt} \% \mathrm{Pt} / \mathrm{HZSM}-5$. The results demonstrated the presence of aggregated particles Pt (0) nanoparticles, which show a lattice distance of $0.28 \AA$ that corresponding well to the Pt (110). Subnano Pt clusters encapsulated in the channel of the zeolite were identified, which in the most case quickly eclipse due to the fast etching of the zeolite framework under high-energy electrons. 
Table S2. Structural parameters of the $0.5 \mathrm{wt} \% \mathrm{Pt} / \mathrm{HZSM}-5$ catalyst obtained by fitting the EXAFS data.

\begin{tabular}{|l|l|l|l|l|l|l|}
\hline Sample & Shell & $\begin{array}{l}\text { Coordination } \\
\text { number }\end{array}$ & $\begin{array}{l}\text { Path } \\
\text { distance } \\
\mathrm{R}(\AA)\end{array}$ & $\begin{array}{l}\text { Debye- } \\
\text { Waller } \\
\text { factor } \\
\left(\AA^{2}\right)\end{array} \quad \sigma^{2}$ & $\begin{array}{l}\text { Threshold } \\
\text { energy } \\
\text { correction } \quad \Delta \mathrm{E} \\
(\mathrm{eV})\end{array}$ & $\begin{array}{l}\text { R-Factor } \\
\text { of fitting }\end{array}$ \\
\hline $\begin{array}{l}\text { Before } \\
\text { reaction }\end{array}$ & Pt-Pt & $11.8( \pm 0.65)$ & 2.75 & 0.04 & 6.422 & 0.003 \\
\hline After reaction & Pt-Pt & $10.4( \pm 0.96)$ & 2.74 & 0.04 & 5.754 & 0.006 \\
\hline
\end{tabular}


Table S3. Catalytic results of $\mathrm{C}_{2} \mathrm{H}_{6} / \mathrm{D}_{2}$ exchange over the clean or $\mathrm{NH}_{3}$ pre-adsorbed $0.05 w t \%$ Pt/HZSM-5.

\begin{tabular}{lccccc}
\hline Catalyst & $\begin{array}{c}\text { Conversion } \\
(\%)\end{array}$ & & \multicolumn{4}{c}{ Selectivity (\%) } \\
\cline { 3 - 5 } & & $\mathrm{C}_{2} \mathrm{H}_{5} \mathrm{D}$ & $\mathrm{C}_{2} \mathrm{H}_{4} \mathrm{D}_{2}$ & $\mathrm{C}_{2} \mathrm{H}_{3} \mathrm{D}_{3}$ & $\mathrm{C}_{2} \mathrm{H}_{2} \mathrm{D}_{4}$ \\
\hline Pt/HZSM-5 & 44 & 59.6 & 27.6 & 8.8 & 1.7 \\
Pt/HZSM-5-NH & 24.5 & 41.2 & 27.6 & 18 & 11.6 \\
HZSM-5-NH & $/$ & $/$ & $/$ & $/$ & \\
\hline
\end{tabular}

As shown in the table, while $\mathrm{C}_{2} \mathrm{H}_{6} / \mathrm{D}_{2}$ exchange over the clean Pt/HZSM-5 catalyst shows significant activity at $300^{\circ} \mathrm{C}$, pre-adsorption of $\mathrm{NH}_{3}$ decreased the activity of the catalyst for $5 \quad \mathrm{C}_{2} \mathrm{H}_{6} / \mathrm{D}_{2}$ exchange. Although previous studies by Bhan and Iglesia suggested that H/D exchange of light alkane can be realized over the Brønsted acid sites of zeolites, ${ }^{14}$ the $\mathrm{C}_{2} \mathrm{H}_{6} / \mathrm{D}_{2}$ exchange over the pure $\mathrm{HZSM}-5$ at $300^{\circ} \mathrm{C}$ is negligible in contrast to the high activity over the metal sites. 

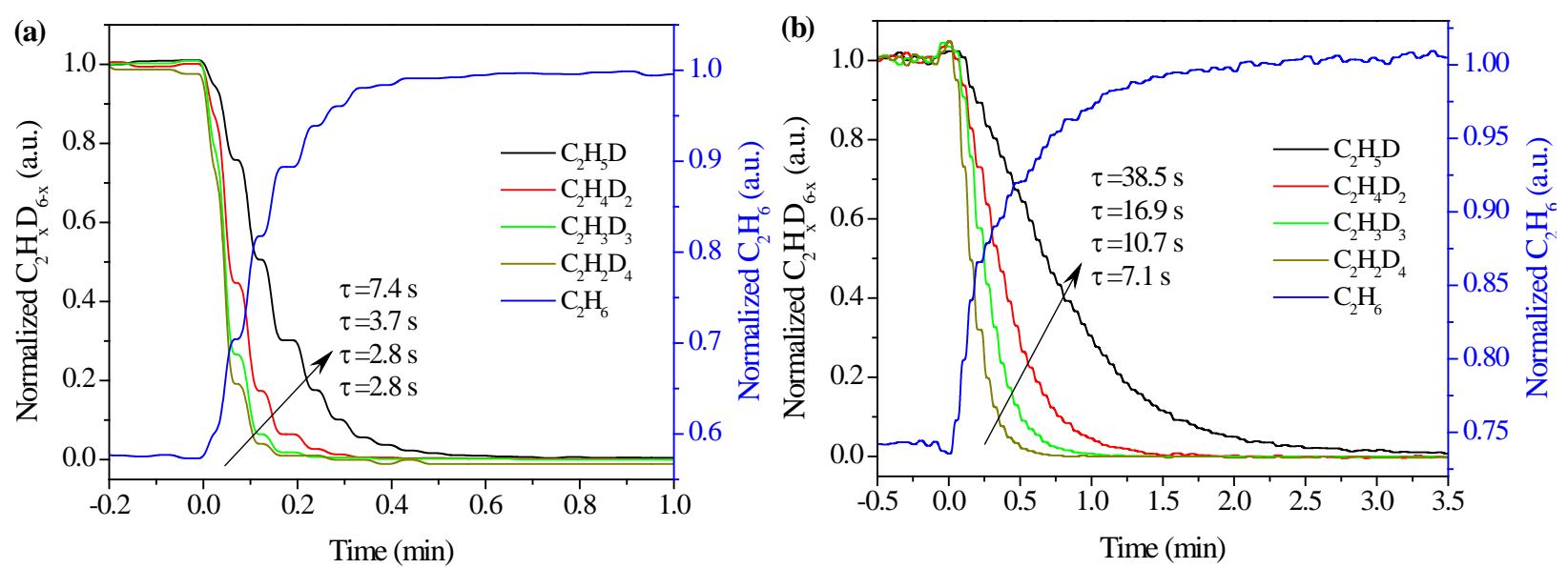

Figure S8. Steady-state isotopic transient results over the clean (a) and $\mathrm{NH}_{3}$ pre-adsorbed (b) 0.05wt\% Pt/HZSM-5 catalyst. The time was set to zero when the reactor influent was switched from $\mathrm{C}_{2} \mathrm{H}_{6} / \mathrm{D}_{2}(20 / 10 \mathrm{ml} / \mathrm{min})$ to $\mathrm{C}_{2} \mathrm{H}_{6} / \mathrm{H}_{2}(20 / 10 \mathrm{ml} / \mathrm{min})$. The time constants for different deuterium exchanged ethane were calculated based on the first-order kinetics:

$$
F_{i}=F_{i, 0} e^{-\frac{t}{\tau}}
$$

where $F_{i}$ is the molar flow during the transient decay, $F_{i, 0}$ is the molar flow during at time $=0$, and $\tau$ is time constant $(\mathrm{k}=1 / \tau)$. The time constant $\tau$ for $\mathrm{C}_{2} \mathrm{H}_{5} \mathrm{D}, \mathrm{C}_{2} \mathrm{H}_{4} \mathrm{D}_{2}, \mathrm{C}_{2} \mathrm{H}_{3} \mathrm{D}_{3}$, and $\mathrm{C}_{2} \mathrm{H}_{2} \mathrm{D}_{4}$ over the clean Pt/HZSM-5 catalyst are 7.4, 3.7, 2.8, and 2.8 s, respectively. However, the time constants for the same products over the $\mathrm{NH}_{3}$ pre-adsorbed Pt/HZSM-5 catalyst are 38.5, 16.9, 10.7, and 7.1 s, respectively. The time constant increased suggested that the presence of $\mathrm{NH}_{3}$ affects the C-H bond activation or there is a hydrogen transfer between $\mathrm{NH}_{3}$ and $\mathrm{C}_{2} \mathrm{H}_{6}$. 

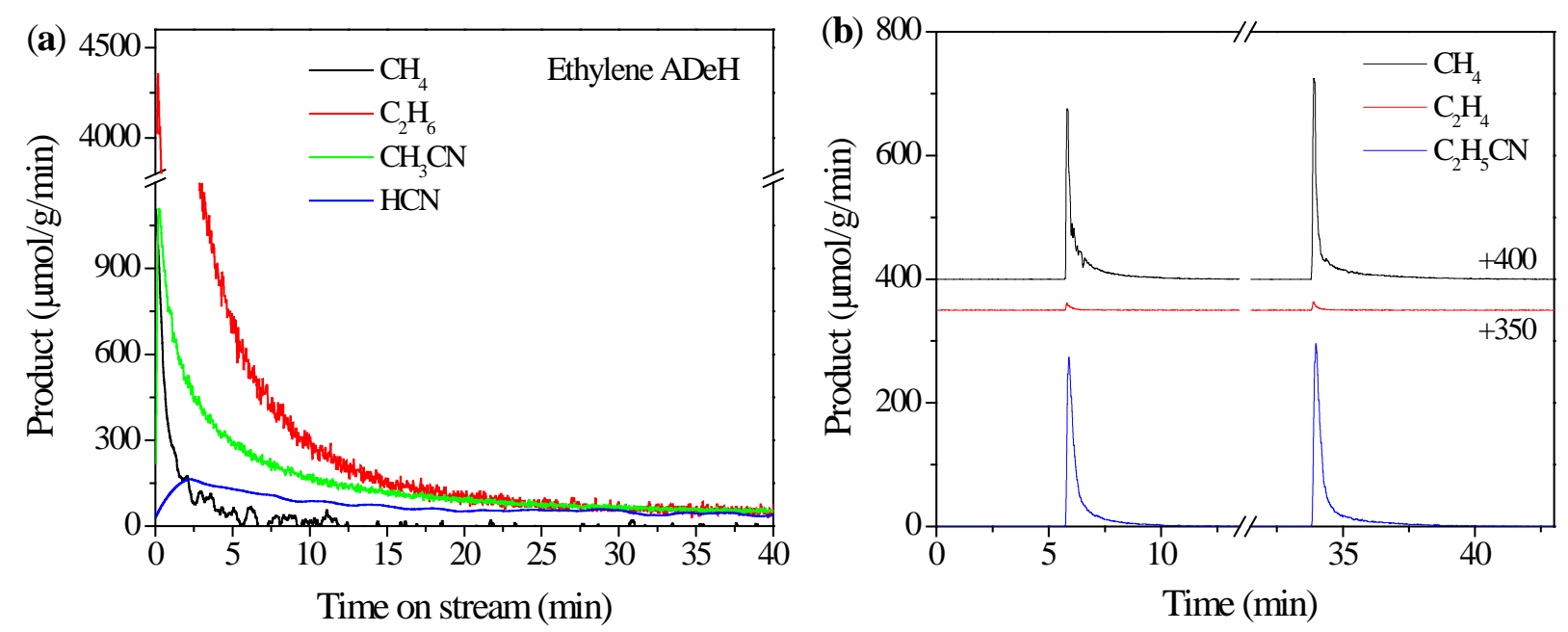

Figure S9. Catalytic data of reactions between possible intermediates and $\mathrm{NH}_{3}$ over $0.1 \mathrm{~g}$ of 0.5 wt\% Pt/HZSM-5 catalyst at 500 ${ }^{\circ} \mathrm{C}$. (a) Between $\mathrm{C}_{2} \mathrm{H}_{4}$ and $\mathrm{NH}_{3}, \mathrm{P}_{\mathrm{C} 2 \mathrm{H} 4} / \mathrm{P}_{\mathrm{NH} 3}=0.5 / 0.5$ atm, GHSV $=16,000 \mathrm{~h}^{-1}$; (b) between $\mathrm{C}_{2} \mathrm{H}_{5} \mathrm{NH}_{2}$ and $\mathrm{NH}_{3}$ through pulse injection of $\mathrm{C}_{2} \mathrm{H}_{5} \mathrm{NH}_{2}$ to $50 \% \mathrm{NH}_{3} / \mathrm{Ar}$ mixture at $16,000 \mathrm{~h}^{-1}$.

The results in panel (a) show very high initial reaction activity between $\mathrm{C}_{2} \mathrm{H}_{4}$ and $\mathrm{NH}_{3}$; however, the rates of different products attenuate with time-on-stream (TOS) significantly during the initial $10 \mathrm{~min}$. The initial rate of $\mathrm{CH}_{3} \mathrm{CN}$ is more than $1000 \mu \mathrm{mol} / \mathrm{g}_{\mathrm{cat}} / \mathrm{min}$, which is higher than that for ethane ADeH, but it decreased to $\sim 70 \mu \mathrm{mol} / \mathrm{g}_{\mathrm{cat}} / \mathrm{min}$ after TOS of $30 \mathrm{~min}$. Additionally, the main product during the early-stage is ethane rather than $\mathrm{CH}_{3} \mathrm{CN}$, the rate of ethane is up to 4300 $\mu \mathrm{mol} / \mathrm{g}_{\mathrm{cat}} / \mathrm{min}$ initially and decreased to also $\sim 70 \mu \mathrm{mol} / \mathrm{g}_{\mathrm{cat}} / \mathrm{min}$ after TOS of $30 \mathrm{~min}$. The higher rate of ethane than that of $\mathrm{CH}_{3} \mathrm{CN}$ suggested the hydrogenation of $\mathrm{C}_{2} \mathrm{H}_{4}$ with $\mathrm{H}_{2}$ from the dehydrogenation (or hydrogen transfer) is dominating on the Pt cluster.

The results in panel (b) show that the direct reaction of ethylamine with $\mathrm{NH}_{3}$ over the Pt/HZSM-5 catalyst produces mainly $\mathrm{CH}_{3} \mathrm{CN}$ and $\mathrm{CH}_{4}$. The formation of $\mathrm{C}_{2} \mathrm{H}_{4}$ is negligible, indicating high activity towards ethylamine dehydrogenation than decomposition. 

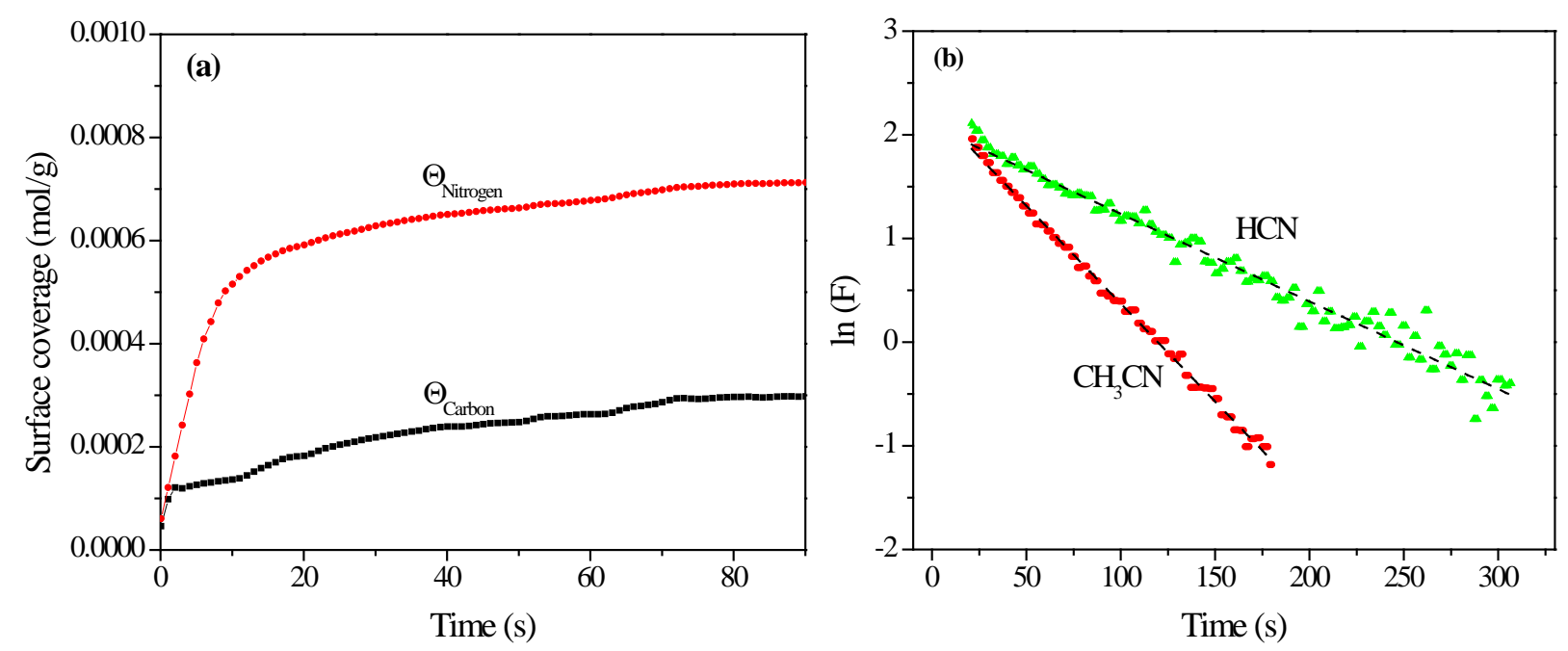

Figure S10. Transient kinetic results. (a) surface coverage of carbon and nitrogen atoms quantified based on the mass balance of the reactor system during the early-stage, see literature for detailed calculation process. ${ }^{15}$ (b) Outlet molecular flow of $\mathrm{CH}_{3} \mathrm{CN}$ and $\mathrm{HCN}$ as a function of time during back-transient experiment. The linear relation between $\ln \left(\mathrm{F}_{\mathrm{i}}\right)$ and $\mathrm{t}$ suggested the first-order kinetics, $\ln \left(\mathrm{F}_{\mathrm{i}}\right)=\ln \left(\mathrm{F}_{\mathrm{i} 0}\right)-\mathrm{kt}$. 

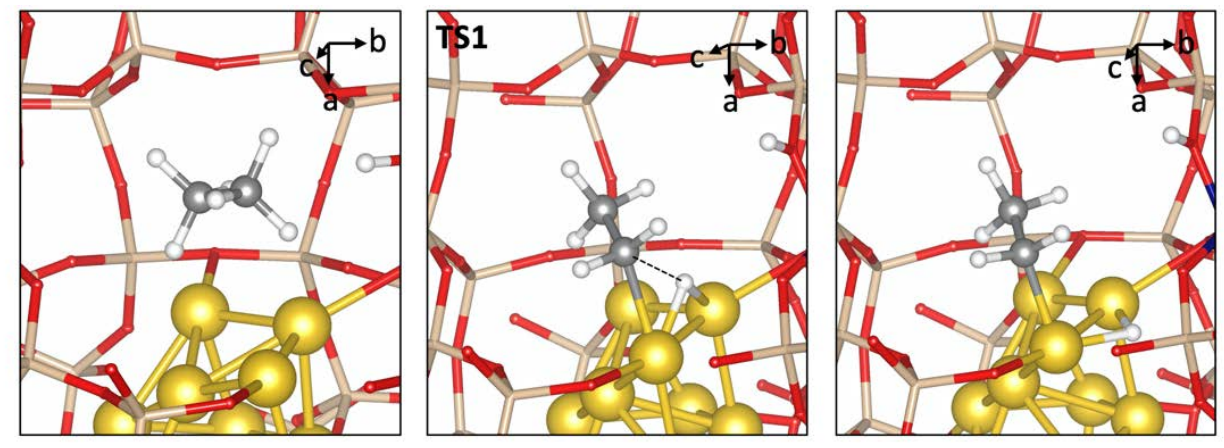

a $\mathrm{Pt}+\mathrm{H}_{3} \mathrm{CCH}_{3}$

Pt-C(-H) $\mathrm{H}_{2} \mathrm{CH}_{3}$

Pt- $\mathrm{CH}_{2} \mathrm{CH}_{3}+\mathrm{Pt}-\mathrm{H}$

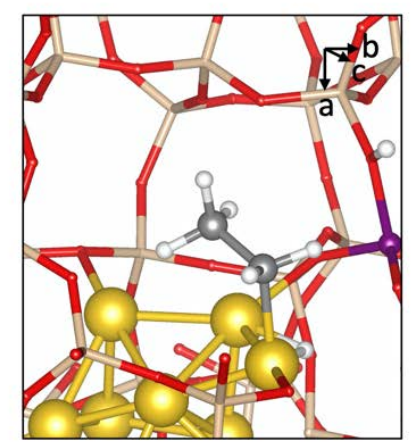

b $\mathrm{Pt}-\mathrm{CH}_{2} \mathrm{CH}_{3}+\mathrm{Pt}-\mathrm{H}$
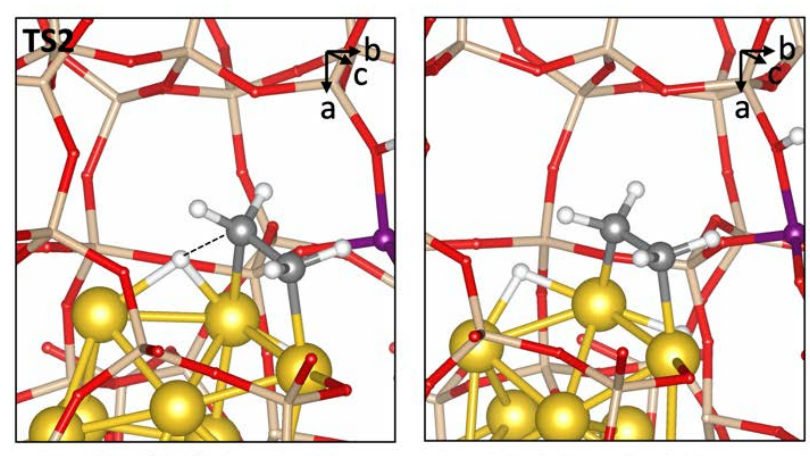

$\mathrm{Pt}-\mathrm{CH}_{2} \mathrm{CH}_{2}+\mathrm{Pt}-2 \mathrm{H}$

Figure S11. Initial, transition, and final states for dehydrogenation of $\mathrm{C}_{2} \mathrm{H}_{6}$ over $\mathrm{Pt}_{20}$ cluster in the HZSM-5. HZSM-5 was shown as wireframe with one Brønsted acid site (purple). Pt atoms are yellow, C, N, and $\mathrm{H}$ are shown as gray, blue, white atoms, respectively. 


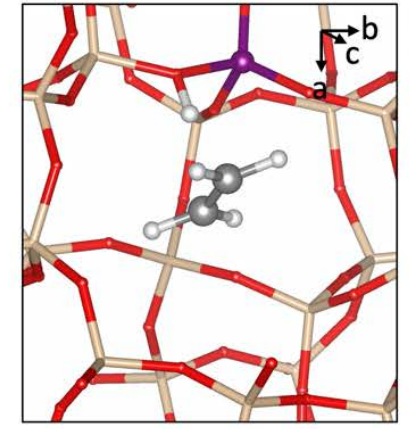

a $\mathrm{Al}-\mathrm{H}+\mathrm{H}_{2} \mathrm{CCH}_{2}$

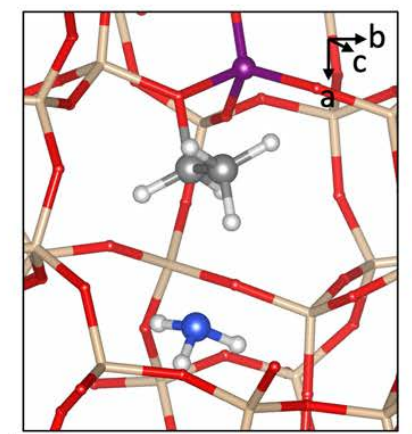

b $\mathrm{Al}-\mathrm{CH}_{2} \mathrm{CH}_{3}+\mathrm{NH}_{3}$

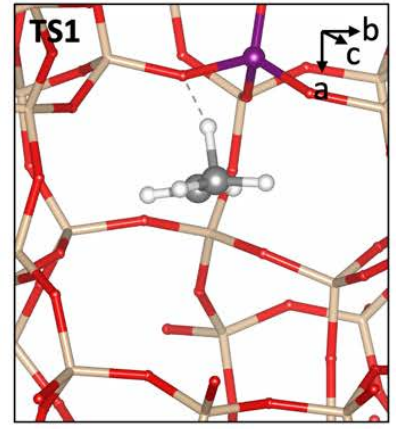

Al-- $\mathrm{HCH}_{2} \mathrm{CH}_{2}$

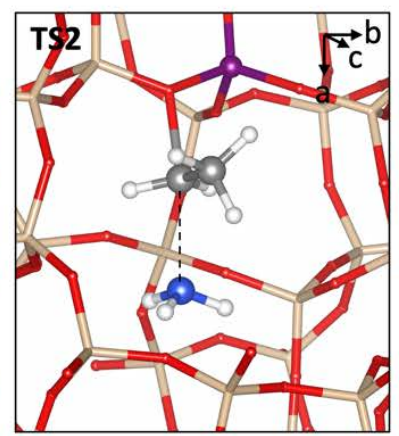

$\mathrm{Al}-\mathrm{C}\left(+\mathrm{NH}_{3}\right) \mathrm{H}_{2} \mathrm{CH}_{3}$

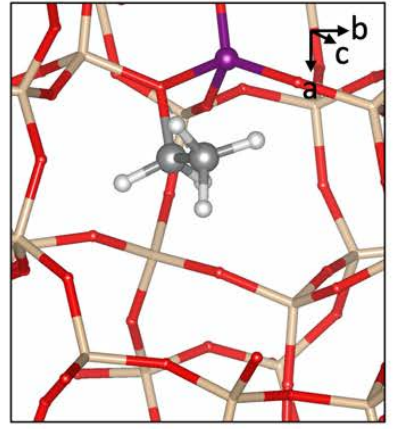

$\mathrm{Al}-\mathrm{CH}_{2} \mathrm{CH}_{3}$

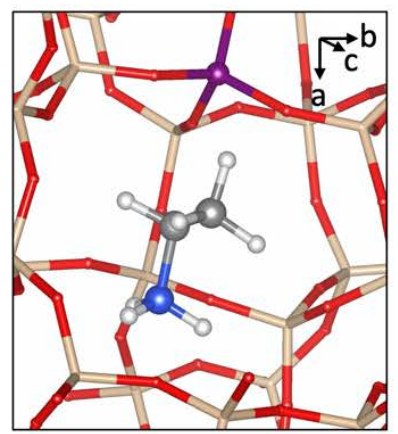

$\mathrm{Al}+\mathrm{CH}_{3} \mathrm{CH}_{2} \mathrm{NH}_{3}$

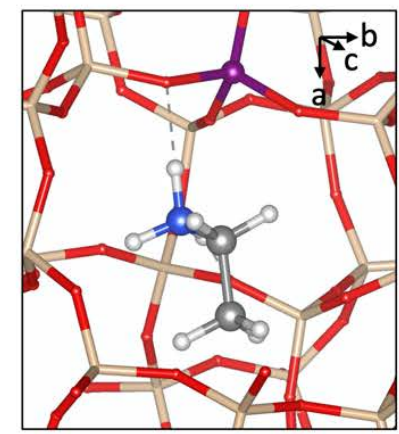

$\mathrm{Al}+\mathrm{H}_{3} \mathrm{NCH}_{2} \mathrm{CH}_{3}$

Figure S12. Initial, transition, and final states for $\mathrm{CH}_{3} \mathrm{CH}_{2} \mathrm{NH}_{2}$ (ethylamine) formation at Brønsted acid site. HZSM-5 was shown as wireframe with one Brønsted acid site (purple). Pt atoms are yellow, $\mathrm{C}, \mathrm{N}$, and $\mathrm{H}$ are shown as gray, blue, white atoms, respectively. 

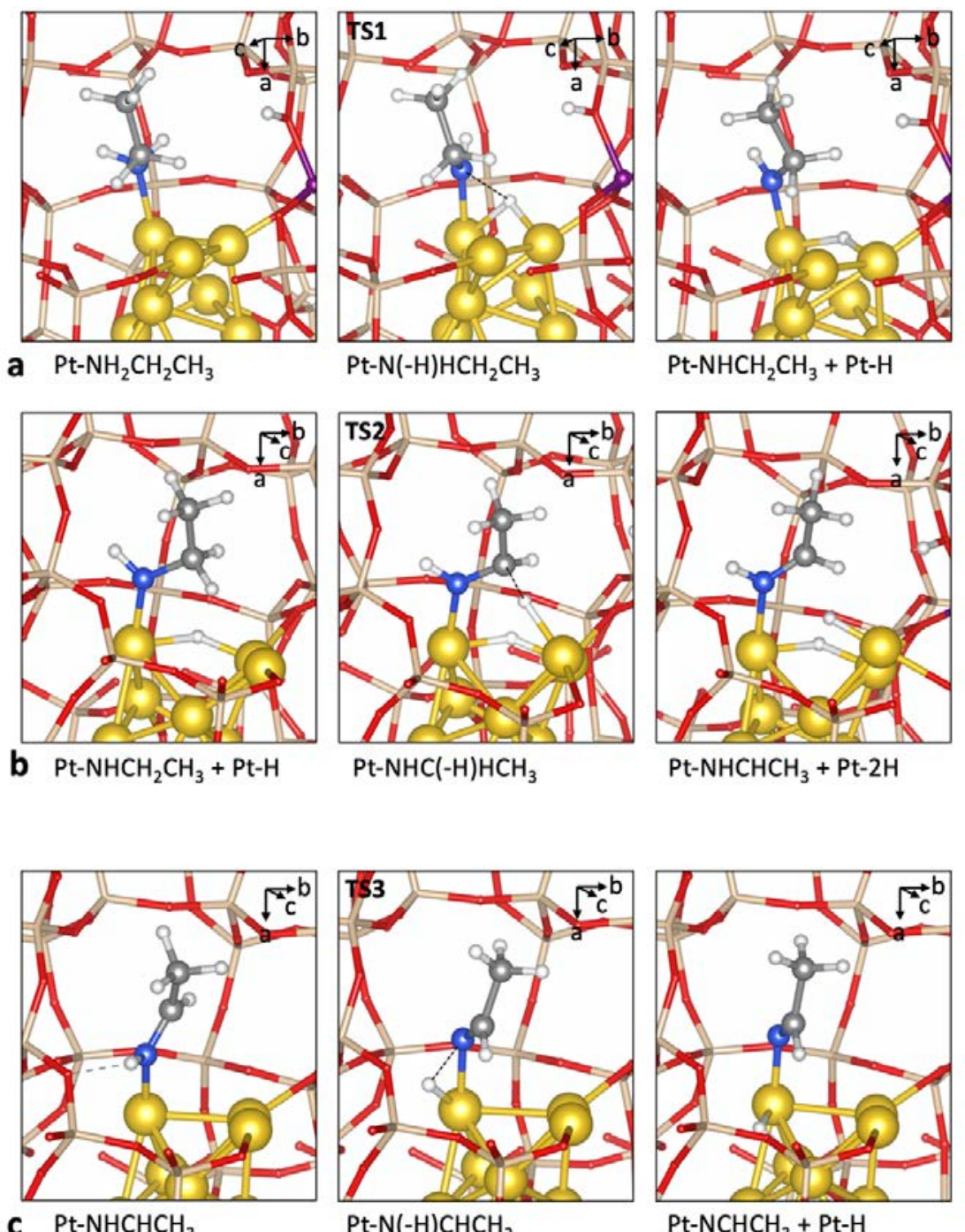

Pt-N(-H) $\mathrm{CHCH}_{3}$
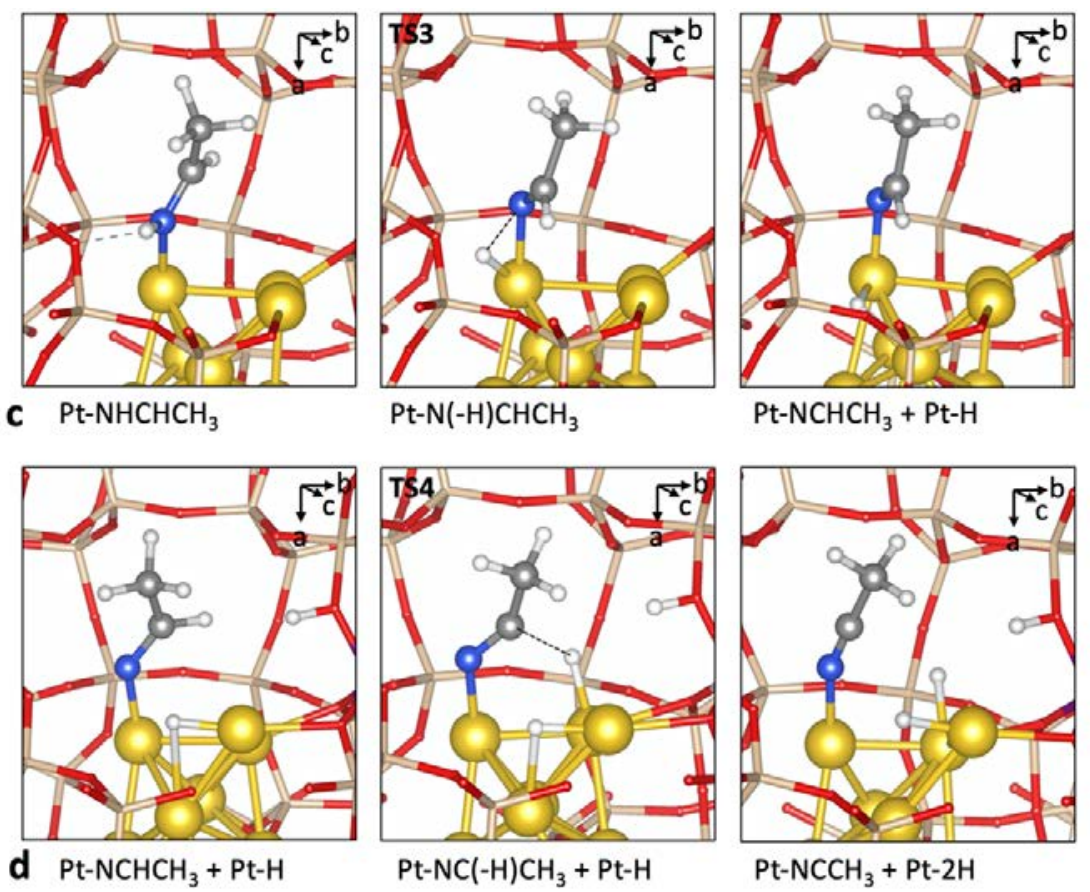

Figure S13. Initial, transition, and final states for $\mathrm{CH}_{3} \mathrm{CN}$ formation over $\mathrm{Pt}_{20}$ in the HZSM-5. HZSM-5 was shown as wireframe with one Brønsted acid site (purple). Pt atoms are yellow, C, N, and $\mathrm{H}$ are shown as gray, blue, white atoms, respectively. 


\section{References:}

1. Schweicher, J. Kinetic and Mechanistic Studies of CO Hydrogenation over Cobalt-based Catalysts. PhD Thesis, Université libre de Bruxelles, 2010.

2. Vilhelmsen, L. B.; Hammer, B., Systematic Study of $\mathrm{Au}_{6}$ to $\mathrm{Au}_{12}$ Gold Clusters on $\mathrm{MgO}(100) \mathrm{F}$ Centers Using Density-Functional Theory. Phys. Rev. Lett. 2012, 108 (12), 126101.

3. Jacobsen, K. W.; Stoltze, P.; Nørskov, J. K., A semi-empirical effective medium theory for metals and alloys. Surf. Sci. 1996, 366 (2), 394-402.

4. Burgess, D. R. Thermochemical Data. NIST Chemistry WebBook, NIST Standard Reference Database 2012, No. 69.

10 5. Lide, D. R. CRC Handbook of Chemistry and Physics; CRC press, 2004; Vol. 85.

6. Li, Y.; N. Armor, J., Ammoxidation of ethane to acetonitrile over Co-beta zeolite. Chem. Commun. 1997, (20), 2013-2014.

7. Galvita, V.; Siddiqi, G.; Sun, P.; Bell, A. T., Ethane dehydrogenation on Pt/Mg(Al)O and PtSn/Mg(Al)O catalysts. J. Catal. 2010, 271 (2), 209-219.

15 8. Sun, P.; Siddiqi, G.; Vining, W. C.; Chi, M.; Bell, A. T., Novel Pt/Mg(In)(Al)O catalysts for ethane and propane dehydrogenation. J. Catal. 2011, 282 (1), 165-174.

9. Wu, J.; Mallikarjun Sharada, S.; Ho, C.; Hauser, A. W.; Head-Gordon, M.; Bell, A. T., Ethane and propane dehydrogenation over PtIr/Mg(Al)O. Appl. Catal. A 2015, 506, 25-32.

10. Yan, B.; Yao, S.; Kattel, S.; Wu, Q.; Xie, Z.; Gomez, E.; Liu, P.; Su, D.; Chen, J. G., Active sites for tandem reactions of $\mathrm{CO}_{2}$ reduction and ethane dehydrogenation. PNAS 2018, 115 (33), 8278-8283.

11. He, Y.; Song, Y.; Laursen, S., The Origin of the Special Surface and Catalytic Chemistry of Ga-Rich $\mathrm{Ni}_{3} \mathrm{Ga}$ in the Direct Dehydrogenation of Ethane. ACS Catal. 2019, 10464-10468.

12. Grant, J. T.; Carrero, C. A.; Goeltl, F.; Venegas, J.; Mueller, P.; Burt, S. P.; Specht, S. E.; McDermott, W. P.; Chieregato, A.; Hermans, I., Selective oxidative dehydrogenation of propane to propene using boron 25 nitride catalysts. Science 2016, 354 (6319), 1570-1573.

13. Lauritzen, A. M.; Madgavkar, A. M., Process for the conversion of lower alkanes to aromatic hydrocarbons. 2014, US8809608.

14. Bhan, A.; Iglesia, E., A Link between Reactivity and Local Structure in Acid Catalysis on Zeolites. Acc. Chem. Res. 2008, 41 (4), 559-567.

30 15. Schweicher, J.; Bundhoo, A.; Kruse, N., Hydrocarbon Chain Lengthening in Catalytic CO Hydrogenation: Evidence for a CO-Insertion Mechanism. J. Am. Chem. Soc. 2012, 134 (39), 16135-16138. 